İş ve İnsan Dergisi I The Journal of Human and Work

Y1l | Year: Nisan | April 2021

Cilt-Sayı | Volume-Issue: 8 (1)

ss I pp: 91-105

doi: 10.18394/iid.873888

e-ISSN 2148-967X

http://dergipark.gov.tr/iid/

\author{
Araştırma Makalesi
}

\title{
Duygusal Emeğin Örgütsel Bağlılığa Etkisi: Konaklama İşletmelerinde Bir Araştırma ${ }^{a}$
}

\author{
The Effect of Emotional Labor on Organizational Commitment: \\ A Research in Accommodation Enterprises
}

Sebahattin Acar ${ }^{b}$, Aydın Çevirgen ${ }^{c}$

MAKALE BILGISII

Anahtar Kelimeler:

Duygusal Emek,

Örgütsel Bă̆lılık,

Konaklama İsletmeleri.

Sinır Birim Çalışanları,

Antalya

Tarihler :

Geliş 3 Şubat 2021

Düzeltme Geliș 8 Mart 2021

Kabul 8 Mart 2021

\section{A R T I C LE IN F O}

\section{Keywords:}

Emotional Labor

Organizational Commitment,

Accommodation Enterprises,

Frontline Employees,

Antalya

Article history:

Received 3 February 2021

Received in Revised Form

8 March 2021

Accepted 8 March 2021
ÖZ

Bu çalışmanın amacı, konaklama işletmelerinde sınır birim çalışanlarının, duygusal emek davranışlarının örgütsel bağlllıklarına olan etkisini incelemektir. Araștırmada tabakalı tesadüfi örnekleme yöntemi kullanılmıştır. Antalya şehir merkezinde bulunan turizm işletme belgeli konaklama ișletmelerindeki sınır birim çalıșanları ile anket çalıșması gerçekleștirilmiștir. 402 katılımcıdan elde edilen verilere korelasyon ve çok değişkenli regresyon analizleri uygulanmıștır. Korelasyon analizi sonuçlarına göre, duygusal emek ile örgütsel bağlllık arasında anlamlı bir iliş̧kiye rastlanılmuştır. Çok değiş̧kenli regresyon analizi sonuçlarına göre ise duygusal emeğin örgütsel bağllllk üzerinde anlamlı bir etkisi olduğu görülmüștür. Ayrica samimi davranış sergileyen çalışanların duygusal bağglllğının daha yüksek olduğu sonucuna ulașılmıștır.

\begin{abstract}
A B S T R A C T
The aim of this study is to investigate the effect of frontline employees' emotional labor behaviors on their organizational commitment in accommodation enterprises. In this research, stratified random sampling method was used. A survey was carried out with the frontline employees in the accommodation enterprises that have tourism operation licensed in the city center of Antalya. Correlation, simple regression and multivariate regression analyzes were performed on data collected from 402 participants. According to the results of correlation analysis, a significant relationship was found between emotional labor and organizational commitment. According to the results of multivariate regression analysis, it was determined that emotional labor has significant effect on organizational commitment. In addition, it was concluded that the affective commitment of the employees who show genuine acting has higher than others.
\end{abstract}

\footnotetext{
a Bu makale ilk yazarın "Duygusal Emek ile Örgütsel Bağlılık Arasındaki İlişki: Konaklama İşletmeleri Çalışanlarına Yönelik Bir Araştırma” başlıkl yüksek lisans tezinden türetilmişstir.

b Doktora Öğrencisi, Alanya Alaaddin Keykubat Üniversitesi, Lisansüstü Eğitim Enstitüsü, Alanya, Türkiye, sebahattin.acar@hotmail.com,ORCID: 0000-0002-5088-1999.

c Illetişim kurulacak yazar, Dr. Öğr. Üyesi, Alanya Alaaddin Keykubat Üniversitesi Turizm Fakültesi, Turizm Işletmeciliği Bölümü, Alanya, Türkiye, aydin.cevirgen@alanya.edu.tr, ORCID: 0000-0002-3245-8783.
} 


\section{GİRIŞ}

Örgütlerde meydana gelen gelişmeler ve yenilikler büyük bir rekabeti de beraberinde getirmektedir. Rekabetin yoğun yaşandığ 1 örgütlerden biri de turizm sektörü içinde bulunan ve emek yoğun özellikte olan konaklama işletmeleridir. $\mathrm{Bu}$ işletmelerin, rekabet gücünü elde edebilmeleri ve bunu sürdürülebilmeleri için misafirleri memnun edebilmeleri gerekmektedir. Misafirlerin memnun edilmesinde ise sınır birim çalışanlarının rolü büyüktür. Sınır birim çalışanları, misafirlerle doğrudan ve yüz yüze iletişimin olduğu departmanlardaki (ön büro, yiyecek ve içecek vb.) işgörenlerdir (Sökmen \& Sezgin, 2017: 238; Walters \& Raybould, 2007: 148). Bu işgörenler misafir ile yüz yüze diyalog halinde oldukları için onların psikolojik yönleri, duygu ve davranışları önemli hale gelmektedir. Bu nedenle günümüzde özellikle hizmet sektöründe yer alan örgütler, çalışanları, duyguları olan bir varlık olarak kabul etmişler ve bu duyguları örgütün yararı için kullanılacak yapılar olarak görmüşlerdir (Man \& Öz, 2009: 76). Bu noktada örgütün yararına olan bu duyguların doğru bir şekilde sergilenmesi için duygusal emek kavramı ortaya çıkmış ve önemi gittikçe artmaya başlamıştır.

Duygusal emek, çalışanlar müşterilerle etkileşim halindeyken, örgütün onlardan istediği olumlu duygu ve davranışları sergilemeleridir (Chu \& Murman, 2006; Morris \& Feldman, 1996). İlk olarak 1983 yılında Arlie Hochschild tarafindan ileri sürülen bu kavram, duyguların yönetimi, duygu ve ruh hallerini içermektedir (Glomb \& Tews, 2004: 5-6). Çalışanların sergilemiş oldukları duygusal emek davranışları ise yüzeysel, derin ve samimi davranış şeklinde belirtilmektedir (Ashforth \& Humpray, 1993; Hochschild, 2003). Konaklama işletmelerinde misafir ile çalışan etkileşiminin genellikle yüz yüze olması, bu işletmelerde sınır birim çalışanlarındaki duygusal emek davranışlarının önemini de artırmaktadır (Çakmakçı \& Öztürk, 2017: 151). Ayrıca misafirlerle diyalog halinde olan çalışanların güler yüzlü olmaları, samimi davranışlar sergilemeleri ve onlara karşı dostane bir yaklaşımda bulunmaları, hizmet kalitesini ve misafir memnuniyetini de artıracaktır (Chu \& Murman, 2006: 1181; Kizanikli \& Ünlüönen, 2016: 503). Bu nedenle, misafirlere sunulan hizmetin kaliteli olması ve misafir memnuniyetini artırması amaciyla duygusal emeğin; yüzeysel, derin ve samimi davranış boyutlarının sergilenmesi, yüz yüze etkileşimin çok olduğu konaklama işletmelerinde önem arz etmektedir (Duran \& Gümüş, 2013: 234). Bu bağlamda konaklama işletmelerinde hizmet sunan sınır birim işgörenlerinin, entelektüel ve fiziksel emeklerinin yanında duygusal emek davranışlarını da sergilemeleri, misafir memnuniyeti açısından önemli hale gelmektedir. Dolayısıla bu emek türlerini sergileyebilen nitelikli çalışanların örgütte tutulmaları, örgütler için son derece hayati bir meseledir. Bu durumda diğer önemli bir konu olan örgütsel bağlıık kavramı karşımıza çıkmaktadır.

Örgütsel bağlılık, çalışanların örgüte olan sadakatleri şeklinde tanımlanmaktadır (Lee, Park \& Yoo, 1999: 62). İlk defa 1956 y1lında Whyte tarafindan incelenen bu kavram, örgütün amaçlarını benimseme, örgüt adına daha çok emek harcama ve örgüt üyeliğini sürdürme konusunda yüksek bir inanışa ve güçlü bir isteğe sahip olma unsurlarını içermektedir (Mowday, Steers \& Porter, 1979: 226). Çalışanların örgütlerine olan bağlılıkları ise duygusal, devam ve normatif bağl1lik olarak görülmektedir (Allen \& Meyer, 1990). Konaklama işletmeleri, uzun ve zor çalışma saatlerini içinde barındıran, işgören devir hızı yüksek olan, genellikle misafir-çalışan ilişkisine dayalı çalışma gerektiren işletmelerdir (Deery \& Shaw, 1999: 387; Günel, 2009: 140; Subramaniam, McManus \& Mia, 2002: 303-304). Konaklama işletmelerinin bu özelliklerinden dolayı işgören devir hızı genel olarak diğer işletme türlerine göre daha fazla olmaktadır. Bu sebeple konaklama işletmelerinde işgören devir hızını azaltmak, kalifiye ve bilgi birikimi fazla olan çalışanları elde tutmak, bu işletmeler için önem teşkil etmektedir (Pelit \& Kılıç, 2012: 126). Çünkü konaklama işletmelerinin başarılı olabilmelerindeki en önemli unsur nitelikli çalışanlardır (Üngören \& Çevirgen, 2016: 2224). Dolayısıyla nitelikli çalışanların işten ayrılmaları, örgüte ayrıca bir maliyet olacağından insan kaynaklarının örgüte kazandırdığı bu çalışanları, o işletmede tutmaları da görevlerinin önemli bir parçası haline gelmiştir (Avc1 \& Küçükusta, 2009: 36).

$\mathrm{Bu}$ araştırmanın temel amacı konaklama işletmelerinde daimi statüde istihdam edilen sınır birim çalışanlarının duygusal emek davranışlarının örgütsel bağlılıklarına olan etkisini belirlemektir. Yapılan literatür taraması sonucunda duygusal emek davranışlarının çalışanların örgütsel bağlılıklarına olan etkisinin (Abraham, 1999; Ghalandari, Jogh, Imani \& Nia, 2012; Güler, Ocak \& Köksal, 2018; Han \& Kim, 2015; Mikeska, Hamwi, Friend, Rutherford \& Park, 2015; Shukla \& Pandey, 2019; Ye, 2016) farklı alanlarda incelendiği az sayıda çalışmaya ulaşılmıştır. Konaklama işletmelerinde ise bu iki konuyu ele alan sınırlı sayıda çalışmaya (Büyükbeşe \& Aslan, 2019; Rathi, Bhatnagar \& Mishra, 2013) rastlanılmıştır. Gerçekleştirilen çalışmaların azlığı 
yanında, bu çalışmayı diğerlerinden farklı kılan husus, araştırmanın konaklama işletmelerinde özellikle daimi statüde istihdam edilen sınır birim çalışanları ile gerçekleştirilmesi, ayrıca duygusal emek ve örgütsel bağlılığ 1 alt boyutları itibariyle ele almasıdır. Bu bakımdan çalıșmanın önemli olduğu ve ilgili literatüre derinlik ve zenginlik kazandırma yönünde katkı sağlayacağı düşünülmektedir.

\section{KAVRAMSAL ÇERÇEVE}

\subsection{Duygusal Emek}

Duygu kavramı, 1800’lü yıllardan günümüze kadar incelenmekte olan ve önemi gittikçe daha da artan bir kavramdır. $\mathrm{Bu}$ konuya ilișkin yapılan araştırmalar incelendiğinde duygu kavramının psikoloji, sosyoloji, biyoloji gibi çeşitli alanlarda ele alındığ1 görülmektedir (Seçer, 2005: 814). Ancak duyguların iş yaşamındaki varlığı 1980'lerden sonra örgütlere ilişkin çalışma yapan birçok bilim adamının, insana öncelik veren bir yaklaşımla, örgütlerde duygulara daha fazla önem vermesiyle başlamıştır (Hsieh, Yang, \& Fu, 2012: 241).

Duygusal emek kavramı, ilk olarak Hochschild tarafindan 1983 yilında yazılan "The Managed Heart: Commercialization of Human Feeling (Yönetilen Kalp: İnsan Duygularının Ticarileşmesi)" adlı kitapta kullanılmıştır (Pala \& Sürgevil, 2016: 774). Hochschild'e (2003: 7) göre duygusal emek, sergilendiğinde insanlar tarafindan fark edilen mimiksel ve bedensel duyguların yönetilmesidir. $\mathrm{Bu}$ tanım doğrultusunda duygusal emek, çalışma yaşamında fiziksel ve zihinsel emek türlerine ilave edilmesiyle beraber yeni bir emek boyutu olarak ele alınmaktadır (Kaya \& Özhan, 2012: 110). Ashforth ve Humpray (1993: 88) ise duygusal emek kavramını, hizmetin verildiği o anki süreçte örgüt tarafindan istenilen duyguların sergilenmesi olarak tanımlamışlardır. Özetle duygusal emek, işyerinde istenilen duyguların çalışanlar tarafından uygun bir şekilde sergilenmesidir.

Literatürde duygusal emek konusunda, Hochschild yaklaşımı, Ashforth ve Humphrey yaklaşımı, Morris ve Feldman yaklaşımı, Grandey yaklaşımı gibi farklı yaklaşımlar bulunmaktadır. En çok kabul gören yaklaşımlardan biri olan Hochschild yaklaşımında, çalışanlar aktöre, müşteriler izleyiciye ve işgörenler ile müşterilerin etkileşimde oldukları yer ise sahneye benzetilmiştir (Grandey, 2000: 96). Diğer yaklaşım ise Ashforth ve Humphrey yaklaşımıdır. Söz konusu yaklaşımın Hochschild'in yaklaşımından fark1, Hochschild duyguların yönetilmesi konusunu vurgularken,
Ashforth ve Humphrey ise duyguların yönetilmesinden çok gözlenebilir davranışlara yoğunlaşmıştır (Grandey, 2000: 96). Hochschild'in (1983) çalışmasında yer alan yüzeysel ve derin davranışa ilaveten Ashforth ve Humphrey (1993: 94) samimi (doğal) davranışı ekleyerek duygusal emek boyutuna katkıda bulunmuşlardır. Bu katkı ile beraber duygusal emek boyutları üç şekilde ele alınmıştır.

Yüzeysel Davranış. Bireyin gerçekte hissetmediği duygular1, yüz ve mimik ifadeleriyle ya da ses tonuyla hissediyormuş gibi sergilemesi yüzeysel davranışı ifade etmektedir (Hochschild, 2003). Çalışanlar, hissettiği duygular yerine örgütün sergilenmesini istediği duyguları göstermek için kendi duygularını düzenler ve kontrol ederler (Sohn \& Lee, 2012: 118). Yüzeysel davranış sergileyen çalışan, negatif duygularını bastırmak için duygusal bir maske takınır ve müşteriye karşı olumlu bir tutum sergilemek için ise sahte duygularla rol yapmaya çalışır (Kalaycı, Özkul, \& Oğuz, 2017: 642).

Derin Davranış. Derin davranış, bireyden sergilenmesi beklenilen duyguları bireyin gerçekten hissetmeye çalışmasıdır (Ashforth \& Humphrey, 1993: 93). Derin davranış sergileyen işgören, duygularını şekillendirerek kendini müşterilerin yerine koyar ve empati kurarak onları anlamaya çalışır (Rupp, McCance, Spencer, \& Sonntag, 2008: 4).

Derin davranış ile yüzeysel davranış arasında belirli farklar bulunmaktadır. $\mathrm{Bu}$ farklar şu şekilde belirtilebilir (Ashforth \& Humphrey, 1993: 93; Grandey, 2003: 87; Karakaş, 2017: 83; Oğuz \& Özkul, 2016: 133; Yürür \& Ünlü, 2011: 86):

- Derin davranışta, duyguların, davranış kuralları ile uyumlu olması gerekir. Yüzeysel davranışta ise işgörenin esasen ne hissettiği önemli olmayıp davranış kurallarına uyması gereklidir.

- Yüzeysel davranışta, bireyin dişa dönük davranışlarına yoğunlaşması söz konusu iken derin davranışta ise kişinin içsel duygularına odaklanma söz konusudur.

- Yüzeysel davranışta, olumsuz duygular (öfke vb.) bastırılırken, derin davranışta ise olumlu duygular (hoşgörü vb.) hissedilmeye çalışılır.

- Derin davranışta, iyi niyet vardır, yüzeysel davranışta ise iyi niyet söz konusu değildir.

- Yüzeysel davranışta, çalıșanın hisleri önemli değildir ve çalışan sadece işini yapar, derin 
davranışta ise çalışan duygularını sergilerken bunları gerçekten hissetmeye çalışır.

Derin ve yüzeysel davranış boyutlarında farklılıklar bulunmasına rağmen her ikisinin de ortak noktaları bulunmaktadır. Derin ve yüzeysel davranış boyutlarında emek harcanması gereklidir (Grandey, 2003: 87; Yürür \& Ünlü, 2011: 86) ve yine her iki boyutta da işletmenin istediği davranış kurallarına göre hareket edilmesi söz konusudur (Karakaş, 2017: 83).

Samimi Davranış. Çalışanın, gösterilmesi istenilen duyguları içten ve doğal olarak sergilemesidir (Ashforth \& Humphrey, 1993: 94). Diğer bir ifadeyle işgörenin, müşteriye rol yapmaksızın duygularını olduğu gibi sergilemesidir (Duran \& Gümüş, 2013: 237).

Samimi davranışta, içten gelen duygu ve davranışlar sergilenirken hiçbir şekilde maskeleme veya rol yapılmamaktadir. Sergilenen bu duygu ve davranışlar genellikle doğal bir şekilde kendiliğinden meydana gelmektedir (Işık, Işık, \& Tırak, 2016: 120). Ayrıca işgörenlerden sergilenmesi beklenen duygular ile onların gerçekte sahip oldukları hisler birbiriyle uyum içinde olduğundan duyguları düzenleme konusunda fazladan bir çaba harcamaya gerek kalmamaktadır (Mesmer-Magnus, DeChurch \& Wax, 2012: 13).

\section{2. Örgütsel Bağlılık}

Örgütlerde bireylerin rol ve davranışlarına ilişkin çalışmalar eskilere dayansa da 1970'li yıllardan itibaren örgütsel alanlarda örgütsel bağlılık konusu daha fazla araştırılmaya başlanmıştır (Aslan, 2017: 33). İşverenlerin, çalışanları makineler gibi herhangi bir üretim faktörü olarak görüp onlara yatırım yapmaması ve onlara gereken önemi vermeyip çok çabuk işten çıkarması örgütlere zarar vermeye ve örgütlerin maliyetlerini artırmaya başlamıştır (Bayraktaroğlu, Yılmaz, \& Can, 2014: 106). Bu olumsuzluklar sonucunda işgörenler, sıradan bir üretim faktörü olmaktan çıkmış diğer üretim faktörlerini yöneten, yaratıcı ve rekabet sağlayıcı önemli varlıklar olarak düşünülmeye başlanmıştır. $\mathrm{Bu}$ nedenle çalışanın yani insan kaynağının örgütsel bağlılığını sağlama konusu ortaya çıkmıştır (Bakan, 2018: 40-41).

Örgütsel bağlılığ1 ilk tanımlayanlardan biri olan Grusky (1996) bu kavramı "bireyin örgüte olan bağlılığının gücü" şeklinde tanımlamıştır (Grusky, 1996'dan aktaran Tetik, 2012: 277). Allen ve Meyer (1996: 252) ise örgütsel bağlılığ1, işgörenin örgütten gönüllü olarak ayrılma isteğini azaltan, çalışan ile örgüt arasındaki psikolojik bağ olarak ifade etmişlerdir.
Örgütsel bağlılığa ilişkin literatür incelendiğinde, en çok Allen ve Meyer'in yaklaşımı üzerinde durulduğu görülmektedir. Bu yaklaşımda örgütsel bağlılığın çalışan ve örgüt arasındaki karşılıklı ilişkiden doğan psikolojik bir tutum olduğu vurgulanmaktadır (Allen \& Meyer, 1990: 2).

Allen ve Meyer, 1984 yılında geliştirmiş oldukları duygusal bağlılık ve devam bağlılığı boyutlarına, Weiner ve Vardi'nin 1980 yılındaki çalışmasından faydalanarak geliştirdikleri normatif bağlılık boyutunu 1990 yılında kendi yaklaşımlarına ekleyerek bağlılık boyutlarını üç şekilde ele almışlardır (Allen \& Meyer, 1990: 3; Wasti, 2002: 526).

Duygusal Băglılık. Çalışanın örgütüyle olan bütünleşmesi ve örgütüne karşı olan bağlılık hissiyatıdır. Duygusal bağlılığı yüksek olan çalışanların, örgütte kalma nedenleri ihtiyaçtan çok isteklerinden kaynaklanmaktadır (Balay, 2014: 27).

Devam Băğlılı̆ğ. Çalışanın örgütten ayrıldı̆̆ takdirde bu durumun, maliyetli olacağına kanaat getirmesi sonucu örgütten ayrılmayıp üyeliğini devam ettirmesidir. Devam bağlılığ işgören, çıkarları doğrultusunda hareket etmekte ve zarara uğramamak için örgütte çalışmaya devam etmektedir (Çolakoğlu, Ayyıldız, \& Cengiz, 2009: 78-79).

Normatif Bağlllık. Örgüte karşı hissedilen sorumluluk sonucu oluşan bağlılıktır. Çalışan, yükümlülükten dolayı örgütte çalışmaya devam etmektedir (Allen \& Meyer, 1996: 253). Bu bağlılığ1 yüksek olan çalışanlar, kişisel çıkarlardan ziyade doğru ve ahlaki olduğunu düşündükleri davranışları sergilemektedirler (Wiener, 1982: 421).

Üç bağl1lık türünde de işgörenler örgütte çalışmaya devam etmektedirler. Fakat duygusal bağlılı̆g yüksek olan bir çalışan, örgütsel üyeliğini istediği için, devam bağlılığ 1 yüksek olan bir çalışan, örgütsel üyeliğini gereklilikten dolayı sürdürmektedir. Normatif bağl1lığ 1 yüksek olan çalışan ise örgütsel üyeliğini doğru (ahlaki) bir davranış olduğuna inandığı için bunu bir yükümlülükten dolayı devam ettirmektedir (Arbak \& Kesken, 2005: 65-66; Balay, 2014: 28; Meyer, Allen \& Smith, 1993: 539). Ayrıca bu üç boyut, birer bağlılık çeşidi olmaktan ziyade bağlılığın farklı bileşenleri olarak ele alınmaktadır. Çünkü çalışan, bu üç bağlılık formunu aynı anda ya da birbirinden farklı derecelerde hissedilebilmektedir (Çöl \& Gül, 2005: 294). 


\subsection{Değişkenler Arası İlişsiler ve Hipotezler}

Duygusal emek, örgütün istekleri doğrultusunda çalışanın, duygularını kontrol ederek emek sürecine dahil etmesidir (Delen, 2017: 80). Bu noktada Hochschild (1983), çalışanların duygularını işletmenin istekleri doğrultusunda kontrol ederek yüzeysel veya derin davranış sergilemeleri gerektirdiğinden dolayı duygusal emeği olumsuz olarak ele almaktadır. Çünkü Hochschild (1983) çalışanların gerçekte hissetmedikleri duyguları sergilemek zorunda kaldıklarında duygusal uyumsuzluk yaşayabileceklerini vurgulamaktadır.

Hochschild'in (1983) bu yaklaşımından hareketle bazı araştırmacılar (Büyükbeşe \& Aslan, 2019; Han, Shim \& Choi, 2018; Nikmah \& Sulistyarini, 2017) duygusal emeği bütüncül ve olumsuz bir şekilde ele almışlardır. Ancak duygusal emeğe ilişkin yapılan çalışmalarda duygusal emeğin hem olumlu hem de olumsuz sonuçlarının olduğu ve olumsuz sonuçlarının yüzeysel davranış ile, olumlu sonuçlarının ise derin davranış ile ilişkilendirildiği görülmektedir. Ayrıca Ashforth ve Humphrey'in (1993) yaklaşımında yer alan, çalışanların müşterilerle iletişim halindeyken herhangi bir çaba sarf etmeden, duygularını doğal bir şekilde sergiledikleri samimi davranış boyutunun da olumlu sonuçları bulunmaktadır. Ancak çoğu çalışmada samimi davranış boyutunun ele alınmadığ 1 görülmektedir (Yürür \& Ünlü, 2011). Konaklama işletmelerinde çalışanların, misafirlere karşı samimi ve içten davranış sergilemeleri, verilen hizmete bir değer katmakla beraber çalışanların misafirlere dostane ve hoş tutumlarla yaklaşmaları, misafirlerin tatmin olmalarıyla, bağlılıklarının ve sadakatinin artmasıyla ilişkilendirilmektedir (Chu \& Murman, 2006: 1181). Dolayısıyla bu çalışmada, yüzeysel ve derin davranış boyutlarına ilave olarak samimi davranış boyutu da dahil edilmiş ve duygusal emeği bir bütün olarak ele almak yerine duygusal emeğin olumlu (derin ve samimi davranış) ve olumsuz (yüzeysel davranış) sonuçlarından hareketle duygusal emek boyutlarının çalışanlar üzerindeki etkileri ayrı ayrı incelenmiştir.

Yüzeysel davranışta, hissedilen duygular yerine, örgütün istediği duyguların sergilenmesi söz konusudur ve bu doğrultuda çalışanlar, kendi duygularını düzenler ve kontrol ederler (Sohn \& Lee, 2012: 118). Yüzeysel davranışa ilişkin yapılan çalışmalarda genellikle örgüt tarafından istenen duygular ile çalışan duyguları arasında bir çelişki bulunmaktadır. $\mathrm{Bu}$ nedenle çalışanlar daha fazla duygusal emek harcamaktadırlar. Literatürde duygusal emeğin örgütsel bağlılığa etkisine ilişkin yapılan çalışmalara bakıldığında; Abraham (1999), çalışmasında yüzeysel davranış olarak bilinen duygusal uyumsuzluğun, müşteri temsilcileri çalışanlarının örgütsel bağlılığını azalttığını ifade etmektedir. Rathi vd. (2013), konaklama sektöründe çalışanlar üzerine yaptıkları çalışmada, yüzeysel davranış sergileyen çalışanların duygusal bağlılıklarının düşük olduğu sonucuna ulaşmışlardır. Benzer şekilde Shukla ve Pandey'de (2019) yüzeysel davranışın, okul öğretmenlerinin duygusal bağlılıklarını olumsuz etkilediğini belirlemişlerdir. Buna karşın, Mehra (2015) çağrı merkezi çalışanlarının ve Ye (2016) ise doktorların yüzeysel davranışlarının onların duygusal bağlılıklarını olumlu yönde etkilediğini tespit etmişlerdir. Belirtilen araştırma sonuçları ve ilgili literatür doğrultusunda aşağıdaki hipotezler oluşturulmuştur.

H1a: Yüzeysel davranışın duygusal bağlılık üzerinde negatif yönde anlamlı bir etkisi vardır.

H1b: Yüzeysel davranışın devam bağlılı̆̆l üzerinde pozitif yönde anlaml bir etkisi vardır.

H1،: Yüzeysel davranışın normatif bağlılık üzerinde negatif yönde anlamlı bir etkisi vardır.

Derin davranış, çalışanın duygularını şekillendirerek kendini müşterilerin yerine koyması ve empati kurarak onları anlamasıdır (Rupp vd., 2008: 4). Duygusal çaba olarak da bilinen derin davranış boyutunda, çalışan istenilen davranışlar ile kendi duygularını düzenlemeye ve uyumlu hale getirmeye çalışır (Grandey, 2003: 87; Karakaş, 2017: 83). Literatürdeki araştırmalara bakıldığında, Ghalandari vd. (2012) hizmet sektörü çalışanlarına yönelik yaptıkları araştırmada derin davranışın örgütsel bağlılığı pozitif yönde anlamlı şekilde etkilediğini belirlemişlerdir. Ye, 2016 yılındaki çalışmasında, doktorların hastaları ile arasında derin davranış sergilemeleri onların duygusal bağlılıklarını pozitif yönde etkilediği sonucuna ulaşmıştır. Shukla ve Pandey'in (2019) çalışmasında ise derin davranışın, devam bağlılığını pozitif yönde anlamlı bir şekilde etkilediği sonucuna ulaşılmıştır. $\mathrm{Bu}$ çalışmaların sonuçlarından ve ilgili literatürden hareketle aşağıdaki hipotezler ortaya koyulmuştur.

H2a: Derin davranışın duygusal bağlılık üzerinde pozitif yönde anlaml bir etkisi vardir.

H2b: Derin davranışın devam bă̆lılı̆̆ üzerinde negatif yönde anlaml bir etkisi vardir.

H2،: Derin davranışın normatif bağlılık üzerinde pozitif yönde anlaml bir etkisi vardır. 
Samimi davranış, çalışanın rol yapmadan duygularını olduğu gibi sergilemesidir (Duran \& Gümüş, 2013: 237). Samimi davranış boyutunda, çalışanın duyguları ve davranışları içtendir. Çalışan, herhangi bir maskeleme ya da rol yapmamaktadır. Sergilenen duygular genellikle doğal olmaktadır (Işık vd., 2016: 120). Duygusal uyum olarak da nitelendirilen samimi davranışta, kişi herhangi bir çaba harcamadan duygularını sergilemektedir (Naring, Briet \& Brouwers, 2006: 304). Literatürde samimi davranış ile örgütsel bağlılık boyutlarına yönelik yapılan araştırmalara bakıldığında; Mehra (2015) çalışmasında, çağrı merkezinde çalışanların, duygusal uyum olarak belirttiği samimi davranış sergilemeleri onların örgütsel bağlılıklarını olumlu yönde etkilediğini belirtmiştir. Güler vd. (2018) yaptıkları araştırmada, doğal duygu gösterimi olarak ifade ettikleri samimi davranışın örgütsel bağlılı̆̆ anlamlı şekilde etkilediği sonucuna ulaşmışlardır. Shukla ve Pandey'in (2019) çalışmasında otomatik duygu düzenlemesi olarak belirttikleri samimi davranışın, normatif bağlılığ pozitif yönde anlamlı etkilediği görülmüştür. $\mathrm{Bu}$ açıklamalar ve ilgili literatür 1şığında aşağıdaki hipotezler oluşturulmuştur.

H3a: Samimi davranışın duygusal bağlllık üzerinde pozitif yönde anlamlı bir etkisi vardir.

H3b: Samimi davranışın devam bağlılığ üzerinde negatif yönde anlamll bir etkisi vardir.

H3c: Samimi davranışın normatif bağlılık üzerinde pozitif yönde anlamlı bir etkisi vardir.

\section{YÖNTEM}

\subsection{Araştırmanın Amacı}

Misafir ile çalışan etkileşiminin yüz yüze olduğu konaklama işletmelerinde sınır birim çalışanlarının duygusal emek çabaları diğer sektörlere ve işgörenlere oranla daha fazla olabilmektedir. Ayrıca konaklama işletmelerinde genel olarak işgören devir hızının yüksekliği bu işletmelerde örgütsel bağlılık konusunu ön plana çıkarmaktadır. Belirtilen bu hususlar konaklama sektöründe duygusal emek ve örgütsel bağlılık konularının birlikte incelenmesi gerektiği düşüncesini doğurmuştur. Bu noktadan hareketle bu araştırmanın amacı, konaklama işletmelerinde sınır birim çalışanlarının, duygusal emek davranışlarının örgütsel bağlılıkları üzerindeki etkisini belirlemektir.

\subsection{Araştırmanın Evreni ve Örneklemi}

Bu çalışmada nicel araştırma yöntemi olan tabakalı tesadüfi örnekleme yöntemi kullanılmıştır. Araştırmanın evrenini, Antalya şehir merkezinde (Aksu, Kepez, Konyaaltı ve Muratpaşa) bulunan 1, 2, 3, 4 ve 5 yıldızlı turizm işletme belgeli otel işletmelerindeki sınır birim çalışanları oluşturmaktadır. Özellikle duygusal emek davranışının ölçülmesinde kavramın teorik yapısına uygun olacağı düşünülerek araştırmaya sadece müşterilerle yüz yüze iletişim halindeki sınır birim çalışanlarının bulunduğu departmanlar (ön büro, yiyecek ve içecek vb.) dahil edilmiştir.

Araştırmanın evren ve örneklemini belirlemek için çeşitli hesaplamalar yapılmıştır. 2019 yılı itibari ile Antalya şehir merkezinde turizm işletme belgeli toplam 84 otel işletmesi bulunduğu belirlenmiştir (Kültür ve Turizm Bakanlığı, 2019). Ayrıca, Antalya ilindeki turizm işletme belgeli tesis istatistiklerinden yararlanılmış (Antalya İl Kültür ve Turizm Müdürlüğü, 2014) ve Antalya şehir merkezindeki otel işletmelerinin toplam ortalama yatak sayısı 43387 olarak hesaplanmıştır. Daha sonra bu sayı, otel işletmelerinde çalışan başına düşen yatak sayısını tespit etmek için kullanılmış ve Turizm Bakanlığı tarafından yapılan Turizm Endüstrisi İşgücü Araştırması'nda yer alan otel yıldızlarına göre personel-yatak oranları $\left(1^{*}=0.10\right.$, $\left.2^{*}=0.20,3^{*}=0.24,4^{*}=0.31,5^{*}=0.39\right)$ kullanilarak (Turizm Bakanlığı \& Uluslararası Çalışma Örgütü, 1994, s.83) toplam çalışan sayısı, yani araştırmanın evreni 15480 olarak bulunmuştur. Örneklem sayısının belirlenmesinde ise $n=N t 2 . p . q / d 2(N-$ 1)+t2.p.q formülünden yararlanılmış (Baş, 2006: 47) ve örneklem sayısı 376 olarak hesaplanmıştır.

Araştırmada tabakalı örnekleme yöntemi kullanıldığından tesis türlerinin ana kütle içindeki oranlarına göre (toplam içindeki payı) her tesis türü için uygulanacak anket sayıları belirlenmiştir. $\mathrm{Bu}$ doğrultuda anketlerin 8 'i beş yıldızlı, 3'ü dört yıldızlı, 2'si üç yıldızlı, 2'si iki yıldızlı ve 1'i bir y1ldızlı olmak üzere toplam 16 otel işletmesinde uygulanmasına karar verilmiştir. Daha sonra olasılıklı tabakalı örneklem yöntemi kullanılarak toplam 84 otel işletmesi içinden tesis türlerine göre anket uygulanacak 16 otel kura çekme işlemi ile seçilmiştir.

\section{3. Ölçekler ve Verilerin Toplanması}

$\mathrm{Bu}$ araştırmada veriler anket yolu ile toplanmıştır. Üç bölümden oluşan anket formunun birinci bölümünde, araştırmaya katılanların demografik özelliklerini belirlemek için cinsiyet, medeni durum, eğitim durumu, çalışılan departman, yaş ve 
görev süresi olmak üzere toplamda 6 soru yer almıştır.

Anketin ikinci bölümünde, duygusal emek davranışını ölçmek için Chu ve Murman'ın (2006) geliştirmiş olduğu Turizm Çalışanları Duygusal Emek Ölçeği'nden (HELS: Hospitality Emotional Labor Scale) 4 önerme, Diefendorff, Croyle ve Gosserand'ın (2005) geliştirmiş oldukları ölçekten ise 8 önerme alınmıştır. Ayrıca bu araştırmada duygusal emeğin derin davranış boyutunu ölçmek için yazılan, "misafirlerle etkileşimdeyken sergilemem gereken duyguları gerçek hislerimle uyumlaştırmak için çabalarım" önermesinin de eklenmesi ile toplam 13 soruluk duygusal emek ölçeği oluşturulmuştur. Ölçekte yüzeysel davranış boyutu için 5 , derin ve yüzeysel davranıs boyutları için ise 4'er önerme yer almıştır.

Anketin üçüncü bölümünde ise Meyer vd. (1993) tarafindan oluşturulan örgütsel bağlılık ölçeğindeki önermelerin otel işletmelerine uyarlanmış şekli bulunmaktadır. Meyer vd. (1993) çalışmalarında daha önce Allen ve Meyer (1990) tarafindan geliştirilen 24 önermeli örgütsel bağlılık ölçeğinden 11 önermeyi almışlar ve kendileri de 7 önerme ekleyip bu ölçeği oluşturmuşlardır. Toplam 18 önermeden oluşan örgütsel bağlılık ölçeğinde duygusal bağlilık, devam bağlılığ1 ve normatif bağlılık boyutlarının her biri 6 önerme ile ölçülmüştür. Katılımcıların duygusal emek (13) ile örgütsel bağlılık (18) düzeyleri arasındaki ilişkiyi saptamak için oluşturulan 31 önerme 5'li Likert tipi ölçeğine göre derecelendirilmiştir. Katılma dereceleri: " $1=$ Kesinlikle Katılmiyorum; 2= Katılmıyorum; 3= Kararsızım; 4= Katılıyorum; 5= Kesinlikle Katılıyorum” şeklinde puanlandırılmıştır.

İlgili anket çalışması, araştırmaya izin veren işletmelerdeki gönüllü katılımcılarla gerçekleştirilmiştir. Anket uygulaması 2019 yılı Şubat ve Mart aylarında Antalya şehir merkezinde yaz kış açık olan turizm işletme belgeli otel işletmelerinde çalışan, sınır birim işgörenleri ile düşük sezon olarak belirlenen zaman diliminde yapılmıştır. Bu zaman diliminin seçilmesinin nedeni ise daha doğru ve sağlıklı sonuçlara ulaşmak için yüksek sezondaki yoğunluk sebebi ile çoğu çalışanın anketi dikkatli bir şekilde dolduramaması veya doldurmak istememesinden kaynaklanabilecek hataların önüne geçmektir. Öncelikle Şubat ayında ön test için seçilen 3 adet 4 yıldızlı otel işletmesi sınır birim çalışanlarınca doldurulan 40 anketin güvenilirliği analiz edilmiş ve bu analiz sonucunda

Tablo 1: Duygusal Emek Ölçeğine Ait Faktör ve Güvenilirlik Analizi

\begin{tabular}{|c|c|c|c|c|c|}
\hline & $\begin{array}{l}\text { Faktör } \\
\text { Yükleri }\end{array}$ & $\begin{array}{c}\ddot{O}_{z} \\
\text { Değerler }\end{array}$ & $\begin{array}{l}\text { Varyansı } \\
\text { Açıklama } \\
\text { Oranı (\%) }\end{array}$ & Ortalama & $\begin{array}{c}\text { Güvenilirlik } \\
\text { Cronbach } \\
\text { Alpha ( } \alpha)\end{array}$ \\
\hline Duygusal Emek (Bağımsız Değişken) & & & 79.405 & & 0.77 \\
\hline Faktör 1: Yüzeysel Davranış & & 3.715 & 28.580 & 2.25 & 0.90 \\
\hline 1. Misafirlere karşı gülümsemem genelde samimi değildir. & 0.811 & & & & \\
\hline 2. Misafirlerle ilgilenirken gerçek duygularımı gizlerim. & 0.860 & & & & \\
\hline 3. İşimin gerektirdiḡi duyguları göstermek için rol yaparım. & 0.870 & & & & \\
\hline 4. Misafirlerle etkileşimdeyken keyfim yerindeymiş gibi yaparım. & 0.821 & & & & \\
\hline 5. Misafirlere gerçekte hissettiğimden farklı duygular gösteririm. & 0.866 & & & & \\
\hline Faktör 2: Derin Davranış & & 3.397 & 26.133 & 3.44 & 0.93 \\
\hline $\begin{array}{l}\text { 6. Misafirlere göstermem gereken duyguları gerçekten yaşamak } \\
\text { için çaba harcarım. }\end{array}$ & 0.857 & & & & \\
\hline $\begin{array}{l}\text { 7. Misafirlere sergilemem gereken duyguları hissetmek için çok } \\
\text { çaba gösteririm. }\end{array}$ & 0.897 & & & & \\
\hline $\begin{array}{l}\text { 8. Misafirlere göstermem gereken duyguları içselleştirmek için } \\
\text { çaba harcarım. }\end{array}$ & 0.865 & & & & \\
\hline $\begin{array}{l}\text { 9. Misafirlerle iletişim kurarken sergilemem gereken duyguların } \\
\text { gerçek hislerime uyması için çabalarım. }\end{array}$ & 0.828 & & & & \\
\hline Faktör 3: Samimi Davranış & & 3.210 & 24.692 & 4.04 & 0.92 \\
\hline 10. Misafirlere karş̧ sergilediğim duygular samimidir. & 0.827 & & & & \\
\hline $\begin{array}{l}\text { 11. Misafirlere karşı gösterdiḡim duygular kendiliḡinden ortaya } \\
\text { çıkar. }\end{array}$ & 0.843 & & & & \\
\hline $\begin{array}{l}\text { 12. Misafirlere karşı gösterdiḡim duygular o an hissettiklerimle } \\
\text { uyumludur. }\end{array}$ & 0.837 & & & & \\
\hline $\begin{array}{l}\text { 13. Misafirlerle ilgilenirken çok içten bir konukseverlik } \\
\text { gösterdiğime inanıyorum. }\end{array}$ & 0.810 & & & & \\
\hline
\end{tabular}


duygusal emeğe ilişkin güvenilirlik (Cronbah's Alpha değeri) 0.73 , örgütsel bağl1lığa ilişkin güvenilirlik ise 0.78 olarak tespit edilmiştir. Daha sonra ise Şubat ve Mart aylarında esas uygulamaya geçilmiş ve çalışma sonucunda elde edilen 495 anketten 402'si analiz için uygun bulunmuştur.

Uygun görülen verilerin analizi için istatistik programı kullanılmıştır. Esas analizlere geçmeden önce verilerin normal dağlım gösterip göstermediğini belirlemek için normallik testi uygulanmıştır. Yapılan test sonucunda duygusal emek ölçeğine ilişkin çarpıklık ve basıklık değerlerinin $(-0.603 ; 1.507)$ ve örgütsel bağlılık ölçeğine ilişkin değerlerin ise $(-0.689 ; 0.052)$ olduğu tespit edilmiştir. Literatürde genel olarak çarpıklık (skewness) ve basıklığın (kurtosis) +2.58 ile -2.58 kritik değerler arasında olması gerektiği (Hair Jr, Black, Babin \& Anderson, 2014: 70-71) ileri sürüldüğünden elde edilen bu değerlerden verilerin normal dağılım gösterdiği söylenebilir. Verilerin normal dağıldığ 1 tespit edildikten sonra verilere korelasyon, basit regresyon ve çok değişkenli regresyon analizleri uygulanmıştır.

\subsection{Güvenilirlik ve Faktör Analizi}

Araştırmada kullanılacak ölçekler için güvenilirlik analizi (Cronbach Alfa) ile faktör analizi gerçekleştirilmiş ve bulgular Tablo 1 ve Tablo 2'de gösterilmiştir. Tablo 1 incelendiğinde duygusal emek ölçeğinin güvenilirlik katsayısının 0.77 olduğu görülmektedir. 13 önermeden oluşan bu ölçeğin yüzeysel, derin ve samimi davranış şeklinde adlandırılan üç faktörlü bir yapı oluşturduğu belirlenmiştir.

Tablo 2'de görüleceği üzere, örgütsel bağlılık ölçeğinin güvenilirlik katsayısı 0.90 olarak bulunmuştur. Faktör analizi sonucunda ise örgütsel bağlılık ölçeğinin üç boyutlu bir yapı oluşturduğu görülmüştür. Fakat bu faktör analizi neticesinde

Tablo 2: Örgütsel Bağlılık Ölçeğine Ait Faktör ve Güvenilirlik Analizi

\begin{tabular}{|c|c|c|c|c|c|}
\hline & $\begin{array}{l}\text { Faktör } \\
\text { Yükleri }\end{array}$ & $\begin{array}{c}\ddot{\mathbf{O z}} \\
\text { Değerler }\end{array}$ & $\begin{array}{l}\text { Varyansı } \\
\text { Açıklama } \\
\text { Oranı (\%) }\end{array}$ & Ortalama & $\begin{array}{c}\text { Güvenilirlik } \\
\text { Cronbach } \\
\text { Alpha (a) }\end{array}$ \\
\hline Örgütsel Bağlılık (Bağımlı Değişken) & & & 73.587 & & 0.90 \\
\hline Faktör 1: Duygusal Bağlılık & & 7.122 & 41.893 & 3.78 & 0.94 \\
\hline $\begin{array}{l}\text { 14. Kariyerimin geriye kalan kısmın bu otelde geçirmek beni } \\
\text { mutlu eder. }\end{array}$ & 0,819 & & & & \\
\hline $\begin{array}{l}\text { 15. Bu otelin problemlerini gerçekten kendi problemlerimmiş } \\
\text { gibi hissediyorum. }\end{array}$ & 0.864 & & & & \\
\hline 16. Bu otele karşı güçlü bir "aidiyet duygusu" hissetmiyorum. & 0.865 & & & & \\
\hline 17. Duygusal açıdan kendimi bu otele ait hissetmiyorum. & 0.883 & & & & \\
\hline 18. Bu otelde kendimi "ailenin bir parçası" gibi hissetmiyorum. & 0.879 & & & & \\
\hline 19. Bu otelin benim için oldukça özel bir yeri vardır. & 0.723 & & & & \\
\hline Faktör 2: Devam Bağlılığı & & 3.968 & 23.338 & 3.04 & 0.89 \\
\hline $\begin{array}{l}\text { 20. Şu anda bu otelde çalışmaya devam etmem, benim isteğim } \\
\text { olduğu kadar bir zorunluluktur. }\end{array}$ & 0.757 & & & & \\
\hline $\begin{array}{l}\text { 21. Şu an bu otelden ayrılmayı istesem bile, bu benim için çok } \\
\text { zor olur. }\end{array}$ & 0.808 & & & & \\
\hline 22. Bu otelden şimdi ayrilmaya karar verseydim hayatım büyük & & & & & \\
\hline ölçüde olumsuz etkilenirdi. & 0.850 & & & & \\
\hline $\begin{array}{l}\text { 23. Bu otelden ayrilmayı aklımdan geçirdiğimde çok az } \\
\text { seçeneğimin olduğunu düşünūyorum. }\end{array}$ & 0.817 & & & & \\
\hline $\begin{array}{l}\text { 24. Bu otele kendimden çok şey vermemiş olsaydım, başka bir } \\
\text { yerde çalışmayı düşünebilirdim. }\end{array}$ & 0.757 & & & & \\
\hline $\begin{array}{l}\text { 25. Bu otelden ayrılmanın olumsuz sonuçlarından biri çok az } \\
\text { seçeneğimin olmasıdır. }\end{array}$ & 0.839 & & & & \\
\hline Faktör 3: Normatif Bağlılık & & 1.420 & 8.355 & 3.70 & 0.90 \\
\hline $\begin{array}{l}\text { 27. Benim için avantajlı olsa bile, şimdi bu otelden ayrılmamın } \\
\text { doğru olduğunu düşünmüyorum. }\end{array}$ & 0.819 & & & & \\
\hline 28. Bu otelden şimdi ayrılsaydım, kendimi suçlu hissederdim. & 0.809 & & & & \\
\hline 29. Bu otel benim sadakatimi hak ediyor. & 0.781 & & & & \\
\hline $\begin{array}{l}\text { 30. Bu oteldeki çalışanlara karşı sorumluluk hissettiğim için şu } \\
\text { anda buradan ayrılmam. }\end{array}$ & 0.795 & & & & \\
\hline 31. Bu otele çok şey borçluyum. & 0.781 & & & & \\
\hline
\end{tabular}


Tablo 3: Duygusal Emek ve Örgütsel Bağlılık Alt Boyutları Arasındaki İlişkiye Ait Korelasyon

\begin{tabular}{|c|c|c|c|c|c|c|}
\hline Değişken & $\begin{array}{l}\text { Yüzeysel } \\
\text { Davranıș }\end{array}$ & $\begin{array}{c}\text { Derin } \\
\text { Davranıs }\end{array}$ & $\begin{array}{c}\text { Samimi } \\
\text { Davranıș }\end{array}$ & $\begin{array}{c}\text { Duygusal } \\
\text { Bağlılık }\end{array}$ & $\begin{array}{l}\text { Devam } \\
\text { Bağlılığı }\end{array}$ & $\begin{array}{c}\text { Normatif } \\
\text { Bağlılık }\end{array}$ \\
\hline $\begin{array}{c}\text { Yüzeysel } \\
\text { Davranıs } \\
\text { Derin } \\
\text { Davranış }\end{array}$ & $-0.200^{* *}$ & 1 & & & & \\
\hline $\begin{array}{c}\text { Samimi } \\
\text { Davranış }\end{array}$ & $-0.331^{* *}$ & $0.650^{* * *}$ & 1 & & & \\
\hline $\begin{array}{c}\text { Duygusal } \\
\text { Bağlılık }\end{array}$ & $-0.308^{* "}$ & $0.535^{* *}$ & $0.625^{* *}$ & 1 & & \\
\hline $\begin{array}{l}\text { Devam } \\
\text { Bağlılığı }\end{array}$ & 0.019 & $-0.123^{*}$ & -0.043 & 0.023 & 1 & \\
\hline $\begin{array}{l}\text { Normatif } \\
\text { Bağlılık }\end{array}$ & $-0.266^{\circ}$ & $0.476^{* *}$ & $0.557^{\circ "}$ & $0.693^{\text {*** }}$ & $0.171^{*}$ & 1 \\
\hline
\end{tabular}

normatif bağlılık boyutunda yer alması beklenen 26 numaralı "mevcut işverenimle çalışmaya devam etmek için herhangi bir mecburiyet hissetmiyorum" önermesinin faktör yükü, duygusal bağlılık boyutunda toplanması sonucu ölçekten çıkarılmış ve faktör analizi tekrardan yapılmıştır. Sonrasında literatüre uygun şekilde 17 önermenin duygusal, devam ve normatif bağlılık olarak adlandırılan üç faktör altında toplandığ bir yapı elde edilmiştir.

\section{BULGULAR}

Araştırmanın demografik verileri incelendiğinde; katılımcıların \%56'sının erkek, \%44'ünün kadın, \%56.7'sinin bekar, \%43.3'ünün evli olduğu, eğitim durumlarına bakıldığında \%46'sının üniversite (ön lisans, lisans ve lisans üstü), \%44'ünün lise ve \%10'unun ise ilköğretim mezunu olduğu tespit edilmiştir. Departmanlara göre dağılıma bakıldığında, \%39.1'i yiyecek ve içecek, \%23.4'ü ön büro, \%18.4'ü kat hizmetleri, \%7.7'si misafir ilişkileri, \%5'i güvenlik, \%3'ü satış ve pazarlama, $\% 1.2$ 'si animasyon ve \%2.2'si ise diğer bölümlerde çalışmaktadır. Katılımcıların yaşlarına bakıldığında, \%28.4'ü 26-30 yaş, \%27.6's1 31-35 yaş, \%20.1'i 36-40 yaş, \%12.2'si 41-45 yaş aralığında, \%9'u 25 yaş ve altı ve \%2.7'si 46 yaş ve üzerindedir. Son olarak görev süreleri ele alındığında, katılımcıların \%56'sinın 1-5 y11, \%29.1'inin 6-10 y11, \%14.2'sinin bir yıldan az ve \%0.7'sinin ise 11-15 yıl arasında bulundukları işletmede çalıştıkları belirlenmiştir. Araştırma kapsamında diğer verilere ait korelasyon ve regresyon analizleri ve elde edilen bulgular aşağıda yer almaktadır.

\subsection{Korelasyon Analizi}

Araştırmada, değişkenler arasındaki ilişkiyi ölçmek amacıyla korelasyon analizinden yararlanılmıştır.
Duygusal emek boyutları ile örgütsel bağlılık boyutları arasındaki ilişki Tablo 3 'te sunulmuştur.

Tablo 3 incelendiğinde, duygusal emeğin boyutlarından biri olan yüzeysel davranış ile duygusal ve normatif bağlılık arasında negatif yönlü bir ilişki olduğu ancak devam bağlılığı ile ilişkisi olmadığı görülmektedir. Derin davranışın, örgütsel bağlılığın duygusal ve normatif bağlılık boyutları ile pozitif, devam bağlılı̆g boyutu ile ise negatif yönlü bir ilişkisi olduğu belirlenmiştir. Samimi davranışın ise duygusal ve normatif bağlılıkla pozitif yönlü bir ilişkisi bulunmakta fakat devam bağlılığı ile ilişkisi bulunmamaktadır. Yapılan incelemede en yüksek korelasyonun duygusal emeğin samimi davranış boyutu ile örgütsel bağlılığın duygusal bağlılık boyutu arasında (r= $0.625 ; \mathrm{p}<0.01$ ) olduğu tespit edilmiştir.

\subsection{Regresyon Analizi}

Çalışmada, duygusal emek boyutlarının örgütsel bağlılık boyutları üzerindeki etkisini incelemek için Tablo 4'te sunulduğu gibi çok değişkenli regresyon analizi kullanılmıştır.

Regresyon analizi sonucunda Tablo 4'te, yüzeysel davranışın duygusal bağlılık üzerinde negatif yönde $(\beta=-0.118 ; p<0.01)$ etkisi olduğu görülmektedir. $\mathrm{Bu}$ yüzden H1a hipotezi kabul edilmiştir. Derin davranışın duygusal bağlılık üzerindeki etkisi pozitif yönde anlamlıdır $(\beta=0.226 ; \mathrm{p}<0.001)$. Bu doğrultuda H2a hipotezi kabul görmüştür. Samimi davranışın ise duygusal bağlılığı pozitif yönde $(\beta=$ $0.440 ; \mathrm{p}<0.001)$ etkilediği ve diğer bağımsız değişkenlere görece daha fazla etkiye sahip olduğu söylenebilir. $\mathrm{Bu}$ veriler 1şığında H3a hipotezi de kabul edilmiştir.

Tablo 4'te yüzeysel davranışın $(\beta=0.008 ; \mathrm{p}>0.05)$ ve samimi davranışın $(\beta=0.068 ; \mathrm{p}>0.05)$ devam 
Tablo 4: Duygusal Emek Boyutlarının Örgütsel Bağlılık Boyutları Üzerindeki Etkiye İlişkin Çok Değişkenli Regresyon Analizi

\begin{tabular}{|c|c|c|c|c|c|}
\hline \multicolumn{6}{|c|}{ Duygusal Bağlılık } \\
\hline & B & $\begin{array}{l}\text { Standart } \\
\text { Hata }\end{array}$ & Beta $(\beta)$ & t & p(sig) \\
\hline Sabit & 1.600 & 0.211 & - & 7.594 & 0.000 \\
\hline $\begin{array}{l}\text { Yüzeysel Davranış } \\
\text { (Y.D) }\end{array}$ & -0.112 & 0.038 & -0.118 & -2.934 & 0.004 \\
\hline $\begin{array}{c}\text { Derin Davranış } \\
\text { (D.D) }\end{array}$ & 0.192 & 0.042 & 0.226 & 4.545 & 0.000 \\
\hline $\begin{array}{c}\text { Samimi Davranış } \\
\text { (S.D) }\end{array}$ & 0.439 & 0.051 & 0.440 & 8.517 & 0.000 \\
\hline \multicolumn{6}{|c|}{$\mathrm{R}=0.657, \mathrm{R}^{2}=0.432$, Düzeltilmiș $\mathrm{R}^{2}=0.428, \mathrm{~F}=100.970$, Durbin-Watson $=1.843, \mathrm{p}=0.000$} \\
\hline \multicolumn{6}{|c|}{ Devam Bağlılığı } \\
\hline Sabit & 3.245 & 0.281 & - & 11.563 & 0.000 \\
\hline $\begin{array}{l}\text { Yüzeysel Davranış } \\
\text { (Y.D) }\end{array}$ & 0.008 & 0.051 & 0.008 & 0.160 & 0.873 \\
\hline $\begin{array}{c}\text { Derin Davranıs } \\
\text { (D.D) }\end{array}$ & -0.142 & 0.056 & -0.166 & -2.533 & 0.012 \\
\hline $\begin{array}{l}\text { Samimi Davranış } \\
\text { (S.D) }\end{array}$ & 0.068 & 0.069 & 0.068 & 0.995 & 0.321 \\
\hline \multicolumn{6}{|c|}{$\mathrm{R}=0.133, \mathrm{R}^{2}=0.018$, Düzeltilmiş $\mathrm{R}^{2}=0.010, \mathrm{~F}=2.391$, Durbin-Watson $=1.885, \mathrm{p}=0.068$} \\
\hline \multicolumn{6}{|c|}{ Normatif Bağılık } \\
\hline Sabit & 1.721 & 0.227 & - & 7.572 & 0.000 \\
\hline $\begin{array}{l}\text { Yüzeysel Davranıs } \\
\text { (Y.D) }\end{array}$ & -0.091 & 0.041 & -0.095 & -2.212 & 0.028 \\
\hline $\begin{array}{l}\text { Derin Davranış } \\
\text { (D.D) }\end{array}$ & 0.170 & 0.046 & 0.200 & 3.731 & 0.000 \\
\hline $\begin{array}{l}\text { Samimi Davranış } \\
\text { (S.D) }\end{array}$ & 0.395 & 0.056 & 0.396 & 7.112 & 0.000 \\
\hline
\end{tabular}

bağlılı̆̆1 üzerinde anlamlı bir etkisinin olmadığ görülmüştür. $\mathrm{Bu}$ nedenle $\mathbf{H 1}_{\mathbf{b}}$ ve $\mathbf{H}_{\mathbf{b}}$ hipotezleri reddedilmiştir. Derin davranışın ise devam bağlılığını negatif yönde $(\beta=-0.166 ; \quad \mathrm{p}<0.05)$ etkilediği görülmektedir. $\mathrm{Bu}$ yüzden $\mathbf{H} 2_{\mathbf{b}}$ hipotezi kabul edilmiştir.

Son olarak yüzeysel davranışın normatif bağlılı̆̆ negatif yönde $(\beta=-0.095 ; p<0.05)$, derin davranışın $(\beta=0.200 ; p<0.001)$ ve samimi davranışın $(\beta=$ $0.396 ; p<0.001)$ ise normatif bağlılığ 1 pozitif yönde etkilediği sonucuna ulaşılmıştır. $\mathrm{Bu}$ bulgular 1şığında H1c, H2c ve H3c hipotezleri kabul edilmiştir.

\section{SONUÇ, TARTIŞMA ve ÖNERİLER}

\subsection{Araştırmanın Temel Sonuçları}

Emek yoğun özellikte olan ve çalışan ile misafir arasında yüz yüze iletişimin yüksek olduğu konaklama işletmelerinde, samimi ve derin duygusal emek davranışlarını sergileyen ve örgütsel bağlılığı yüksek olan sınır birim çalışanları önem arz etmektedir. $\mathrm{Bu}$ çalışmada konaklama işletmelerinde daimi statüde istihdam edilen sinır birim çalışanlarının duygusal emeğe ilişkin en çok samimi davranış, sonrasında ise yine yüksek düzeyde derin davranış sergiledikleri, buna karşın çalışanların düşük düzeyde yüzeysel davranış gösterdikleri tespit edilmiştir. Örgütsel bağl1lıkları açısından, en çok duygusal bağliliklarının ve ardından normatif bağlılıklarının yüksek olduğu belirlenmiştir. Devam bağlılıkları ise düşük düzeydedir. $\mathrm{Bu}$ sonuçlar konaklama işletmeleri açısından memnuniyetle karşılanabilecek bir durumdur. Yapılan korelasyon ve regresyon analizlerinden ise; genel olarak duygusal emek boyutları ile örgütsel bağlılık boyutları arasında anlamlı ilişkiler bulunduğu ve sınır birim çalışanlarının duygusal emek davranışlarının örgütsel bağlılıkları üzerinde etkili olduğu sonucuna varılmıștır.

Duygusal emek boyutlarının örgütsel bağlilık boyutları üzerindeki etkisi detaylı incelendiğinde, ilk olarak örgütsel bağlılığın alt boyutu olan duygusal bağlılık üzerinde yüzeysel davranışın negatif yönde anlamlı bir etkisi olduğu tespit edilmiştir. Bu bulgu, Rathi vd. (2013) ve Shukla ve Pandey'in (2019) çalışmaları ile paralellik gösterirken, Ye'nin (2016) çalışmasıyla farklılık göstermektedir. Analiz sonucunda duygusal bağlılık üzerinde derin davranışın ise pozitif yönde anlamlı bir etkisinin bulunduğu belirlenmiștir. $\mathrm{Bu}$ bulgu Ye’nin 2016 yılındaki çalışmasının sonucu ile benzerlik göstermektedir. Son olarak duygusal bağlılık üzerinde samimi davranıșın pozitif yönde anlamlı bir etkisi bulunmuştur. Ayrıca, samimi davranışın duygusal bağlılık üzerindeki etkisinin, duygusal emeğin diğer boyutlarına göre daha fazla 
olduğu tespit edilmiştir. Bu sonuç, Mehra'nın 2015 yılında yaptığı çalışmada samimi davranış olarak tanımladığı duygusal uyumun, örgütsel bağlılı̆̆ diğer bağımsız değişkenlere göre daha çok etkilediği yönündeki bulgusu ile örtüşmektedir.

Daha sonraki analizde örgütsel bağlılığın diğer bir alt boyutu olan devam bağlılığı üzerinde yüzeysel ve samimi davranışın etkisinin olmadığı, sadece derin davranışın işgörenlerin devam bağlılığını negatif yönde anlamlı olarak etkilediği tespit edilmiştir. Shukla ve Pandey 2019 yılında yaptıkları çalışmada ise derin davranışın devam bağlılığını pozitif yönde etkilediği sonucuna ulaşmışlardır.

Araştırmanın diğer bir bulgusu olarak, örgütsel bağlılı̆̆ın son alt boyutu olan normatif bağlılık üzerinde yüzeysel davranışın negatif ve anlamlı, derin ve samimi davranışın ise pozitif ve anlamlı etkileri olduğu tespit edilmiştir. Shukla ve Pandey'in (2019) çalışmasında da samimi davranışın normatif bağlılık üzerinde pozitif ve anlamlı bir etkisinin olduğu belirlenmiştir.

$\mathrm{Bu}$ çalışmada elde edilen sonuçlar ile literatürdeki benzer çalışmaların sonuçları genel olarak paralellik göstermektedir. Ancak bu çalışmadan farklı olan sonuçlarında olduğu görülmektedir. $\mathrm{Bu}$ farklılıkların nedenleri; araştırmacıların duygusal emek ile örgütsel bağlılık konularına ait alt boyutları derinlemesine incelememiş olmalarına, araştırmacılar arasında duygusal emek boyutları konusunda fikir birliğinin olmamasına, araştırmaların farklı alanlarda (eğitim, sağlık, çağrı merkezleri, müşteri temsilcileri gibi) ve daha az örneklem büyüklükleri ile gerçekleştirilmesine bağlanabilir. Konaklama işletmeleri bağlamında ise çok sınırlı olan iki çalışmadan Rathi vd.'nin (2013) Hindistan'daki 204 otel sınır birim çalışanı ile gerçekleştirdikleri araştırmalarında, duygusal emeğin samimi davranış boyutunu kullanmadıkları ve örgütsel bağlılı̆̆ın ise sadece duygusal bağlılık boyutunu ele aldıkları tespit edilmiştir. Büyükbeşe ve Aslan'ın (2019) Gaziantep'teki 4 ve 5 yildızlı otellerdeki 228 çalışan ile yaptıkları çalışmada ise duygusal emeğin örgütsel bağlılık üzerindeki etkisini genel olarak ölçtükleri belirlenmiştir. Ayrıca bu çalışmanın sınır birim çalışanları ile gerçekleştirildiğine dair bir bilgi bulunmamaktadır.

\subsection{Kuramsal ve Pratik Çıkarımlar}

Konaklama işletmeleri sınır birim çalışanları ile gerçekleştirilen bu çalışmada duygusal emek davranışlarının örgütsel bağlılık üzerindeki etkileri ortaya koyulmuştur. Literatürde genelde duygusal emeğin alt boyutları olan yüzeysel ve derin davranış üzerinde durulduğu, samimi davranış boyutunun göz ardı edildiği, ayrıca çok az sayıdaki çalışmanın örgütsel bağlılık alt boyutlarını ele aldığı görülmektedir. $\mathrm{Bu}$ araştırmada duygusal emeğin samimi davranış boyutunun da ele alınması ve örgütsel bağlılık boyutları ile detaylı bir şekilde incelenmiş olması, ayrıca örneklem olarak konaklama işletmelerinde düşük sezonda ve de daimi statüdeki sınır birim çalışanlarının araştırma kapsamına alınması bu çalışmayı diğerlerinden farklı kılmaktadır. $\mathrm{Bu}$ yönüyle araştırma sonuçlarının literatüre katkı sağlaması beklenmektedir.

Araştırma sonuçlarına dayanarak uygulamaya yönelik çıkarımlarda da bulunulabilir. Konaklama işletmeleri yöneticilerinin, daha çok insan kaynakları yöneticilerinin, duygusal emek davranışlarını özelikle de samimi davranışı örgüt kültürü haline getirmeleri, personel işe alım süreçlerinde nitelik ve nicelikle beraber duygusal emek davranışlarına da önem vermeleri gerektiği söylenebilir. Ayrıca konaklama işletmelerinin duygusal emek davranışlarının daha doğru ve iyi sergilenmesi için çalışanlarına bu konuda kurslar ve seminerler vermesi önerilmektedir. Böylece konaklama işletmelerinde sınır birim çalıșanlarının örgütsel bağlılıklarının artırılması ve işgören devir hızının azaltılması sağlanabilir.

\subsection{Kısıtlar ve Öneriler}

Birçok çalışmada olduğu gibi bu çalışmanın da bazı kısıtları bulunmaktadır. Araştırmanın örnekleminin yalnızca Antalya şehir merkezinde, düşük sezonda faaliyet gösteren "Turizm İşletme Belgeli" konaklama işletmelerindeki sınır birim çalışanlarından oluşması bu çalışmanın kısıtları olarak belirtilebilir. Dolayısıyla çalışmanın sonuçlarını farklı bölgelerdeki tüm konaklama işletmeleri çalışanlarına ya da farklı sektörlerdeki çalışanlara genellemek doğru olmayacaktır.

Bundan sonra yapılacak çalışmalarda araştırmacılar, mevsimlik işgörenler ile veya farklı ülke, bölge ve kültürlerde, ayrıca seyahat sektöründe, yiyecek içecek işletmeleri gibi farklı hizmet kollarında yeni çalışmalar yapabilir ve bu çalışmanın sonuçları ile karşılaştırabilirler. Ayrıca araştırmacılara, duygusal emeğin samimi boyutu üzerinde fazla durulmadığ 1 için bu boyutun, başka değişkenler üzerindeki etkisinin de araştırılması önerilmektedir. 


\section{ETIKK BEYANATI}

Destek Bilgisi: $\mathrm{Bu}$ çalışma, kamu, ticari veya kar amacı gütmeyen kuruluşlar gibi herhangi bir organizasyondan destek almamıştır.

Çıkar Çatışması: Tüm yazarlar adına, sorumlu yazar çıkar çatışması olmadığını belirtir.

Etik Onay: İnsan katılımcıları içeren çalışmalarda gerçekleştirilen tüm prosedürler, kurumsal ve / veya ulusal araştırma komitesinin etik standartlarına ve 1964 Helsinki deklarasyonuna ve daha sonraki değişikliklerine veya karşılaştırılabilir etik standartlara uygundur.

Bilgilendirilmiş Onam Formu: Çalışmaya katılan tüm katılımcılar araştırma hakkında bilgilendirilmiş ve gönüllü olarak araştırmaya dahil olmuşlardır.

\section{KAYNAKÇA}

Abraham, R. (1999). The impact of emotional dissonance on organizational commitment and intention to turnover. The journal of Psychology, 133(4), 441-455. doi: 10.1080/00223989909599754

Allen, N. J. \& Meyer, J. P. (1990). The measurement and antecedents of affective, continuance and normative commitment to the organization. Journal of Occupational Psychology, 63(1), 1-18. doi: 10.1111/j.2044-8325.1990.tb00506.x

Allen, N. J. \& Meyer, J. P. (1996). Affective, continuance, and normative commitment to the organization: An examination of construct validity. Journal of Vocational Behavior, 49(3), 252-276. doi: 10.1006/jvbe.1996.0043

Antalya İl Kültür ve Turizm Müdürlüğü (2014). Konaklama tesisi istatistikleri: Belgeli tesislerin tür ve sinıflarına göre dağllımi. 15.01.2019. https://antalya.ktb.gov.tr/TR-175821/konaklamatesisi-istatistikleri.html

Arbak, Y. \& Kesken, J. (2005). Örgütsel bağlllık, să̆llk hizmetlerinde sürekli gelişim için davranışsal bir yaklaşım. İzmir: Dokuz Eylül Üniversitesi Yayınları.

Ashforth, B. E. \& Humphrey, R. H. (1993). Emotional labor in service roles: The influence of identity. Academy of Management Review, 18(1), 88-115. doi: 10.5465/amr.1993.3997508

Aslan, İ. (2017). Öğretmenlerin pozitif psikolojik sermaye algıları ile örgütsel bağglılıkları arasındaki ilişkinin incelenmesi (Yayımlanmamış Yüksek Lisans Tezi). Siirt Üniversitesi, Sosyal Bilimler Enstitüsü, Siirt.

Avcı, N. \& Küçükusta, D. (2009). Konaklama işletmelerinde örgütsel öğrenme, örgütsel bağl1lık ve işten ayrılma eğilimi arasındaki ilişki. Anatolia: Turizm Araştırmaları Dergisi, 20(1), 33-44. Erişim adresi: https://www.anatoliajournal.com/atad/

Bakan, İ. (2018). Örgütsel stratejilerin temeli örgütsel bağlllık: Kavram, kuram, sebep ve sonuçlar. Ankara: Gazi Kitabevi.

Balay, R. (2014). Yönetici ve ögrretmenlerde örgütsel bağlılık. Ankara: Pegem-A Yayıncılık.

Baş, T. (2006). Anket: Anket nasıl hazırlanır? Ankara: Seçkin Yayıncılık.

Bayraktaroğlu, S., Yılmaz, S. E. \& Can, M. (2014). Kurumsal sosyal sorumluluk algisının örgütsel bağl1lığa etkisini belirlemeye yönelik bir araştırma. Siyaset, Ekonomi ve Yönetim Araştırmaları Dergisi, 2(3), $\quad 99-122 . \quad$ Erişim adresi: http://www.siyasetekonomiyonetim.org/index.php/se yad 
Büyükbeşe, T. \& Aslan, H. (2019). Psikolojik sermaye ve duygusal emeğin örgütsel bağl1lık üzerindeki etkisi. İşletme Araştırmaları Dergisi, 11(2), 949-963. Erişim adresi: https://www.isarder.org/

Chu, K. H. L. \& Murrmann, S. K. (2006). Development and validation of the hospitality emotional labor scale. Tourism Management, 27(6), 1181-1191. doi: 10.1016/j.tourman.2005.12.011

Çakmakcı, E. \& Öztürk, Ş. (2017). Duygusal emeğin otel çalışanları üzerinden kavramsal boyutları ile tartış1lması. Süleyman Demirel Üniversitesi FenEdebiyat Fakültesi Sosyal Bilimler Dergisi, (40), 149163. Erişim adresi: https://dergipark.org.tr/tr/pub/sufesosbil

Çolakoğlu, U., Ayyıldız, T. \& Cengiz, S. (2009). Çalışanların demografik özelliklerine göre örgütsel bağlılık boyutlarında algılama farklılıkları, Kuşadası'ndaki beş yıldızlı konaklama işletmeleri örneği. Anatolia: Turizm Araştırmaları Dergisi, 20(1), 77-89. Erişim adresi: https://www.anatoliajournal.com/atad/

Çöl, G. \& Gül, H. (2005). Kişisel özelliklerin bağlılık üzerine etkileri ve kamu üniversitelerinde bir uygulama. Atatürk Üniversitesi İktisadi ve İdari Bilimler Dergisi, 19(1), 291-306. Erişim adresi: https://dergipark.org.tr/tr/pub/atauniiibd

Deery, M. A. \& Shaw, R. N. (1999). An investigation of the relationship between employee turnover and organizational culture. Journal of Hospitality \& Tourism Research, 23(4), 387-400. doi: 10.1177/109634809902300404

Delen, M. G. (2017). Duygusal emek \& tinsel emek. İstanbul: Türkmen Kitabevi.

Diefendorff, J. M., Croyle, M. H. \& Gosserand, R. H. (2005). The dimensionality and antecedents of emotional labor strategies. Journal of Vocational Behavior 66(2), 339-357. doi: 10.1016/j.jvb.2004.02.001

Duran, E. \& Gümüş, M. (2013). Turizm lisans öğrencilerinin duygusal emek deneyimlerinin kariyer tercihlerine etkileri. Dokuz Eylül Üniversitesi Sosyal Bilimler Enstitüsü Dergisi, 15(2), 233-251. Erişim adresi: https://dergipark.org.tr/en/pub/deusosbil

Ghalandari, K., Jogh, M. G. G., Imani, M. \& Nia, L. B. (2012). The effect of emotional labor strategies on employees job performance and organizational commitment in hospital sector: Moderating role of emotional intelligence in Iran. World Applied Sciences Journal, 17(3), 319-326. Retrieved from https://www.idosi.org/index.htm

Glomb, T. M. \& Tews, M. J. (2004). Emotional labor: A conceptualization and scale development. Journal of Vocational Behavior, 64(1), 1-23. doi:

\subsection{6/S0001-8791(03)00038-1}

Grandey, A. A. (2000). Emotional regulation in the workplace: A new way to conceptualize emotional labor. Journal of Occupational Health Psychology, 5(1), 95-110. doi: 10.1037//1076-8998.5.1.95

Grandey, A. A. (2003). When 'the show must go on': Surface acting and deep acting as determinants of emotional exhaustion and peer-rated service delivery. Academy of Management Journal, 46(1), 86-96. doi: doi.org/10.5465/30040678

Güler, M., Ocak, M. \& Köksal, O. (2018). Doğal duygusal emek ve örgütsel bağlllık ilişkisi: Yüzeysel rol yapmanin düzenleyicilik rolü. 17. Uluslararas1 Katılımlı İşletmecilik Kongresi 26-28 Nisan, İzmir Katip Çelebi Üniversitesi, İzmir.

Günel, Ö. D. (2009). Turizm sektöründe mevsimsellik sorunu ve mevsimlik istihdamın çalı̧̧anların örgütsel bağlllıklarına etkisi: Konaklama işletmeleri çalışanlarına yönelik bir araştırma (Yayınlanmamış Doktora Tezi). Dokuz Eylül Üniversitesi, Sosyal Bilimler Enstitüsü, İzmir.

Hair Jr, J. F., Black, W. C., Babin B. J. \& Anderson, R. E. (2014). Multivariate data analysis. London: Pearson Education Limited.

Han, K. \& Kim, T. (2015). The effect of emotional labor, job stress and way of coping on the organizational commitment of nurses in a general hospital. Korean Journal of Stress Research, 23(1), 39-48. doi: 10.17547/kjsr.2015.23.1.39

Han, S. L., Shim, H. S. \& Choi, W. J. (2018). The effect of emotional labor of college administrative service workers on job attitudes: Mediating effect of emotional labor on trust and organizational commitment. Frontiers in Psychology, 9, 1-11. doi: 10.3389/fpsyg.2018.02473

Hochschild, A. R. (2003). The managed heart: The commercialization of human feeling. California: University of California Press.

Hsieh, C. W., Yang, K. \& Fu, K. J. (2012). Motivational bases and emotional labor: Assessing the impact of public service motivation. Public Administration Review, 72(2), 241-251. doi: 10.1111/j.15406210.2011.02499.x

Işık, C., Işık, Z. \& Tırak, L. (2016). Turizm amaçlı konaklama işletmelerinde duygusal emek ile bireysel yenilikçilik ilişkisi: Palandöken örneği. Uluslararası Ekonomi ve Yenilik Dergisi, 2(2), 117-133. doi: 10.20979/ueyd.89822

Kalaycı, I., Özkul, M. \& Oğuz, H. (2017). Şefkat ve ticaret arasında kalan bir çalışma biçimi: Yaşlı bakım hizmetlerinde duygusal emek. Süleyman Demirel Üniversitesi İktisadi ve İdari Bilimler Fakültesi 
Dergisi, 22(3), 637-662. Erişim adresi: https://iibfdergi.sdu.edu.tr/tr

Karakaş, A. (2017). Duygusal emek, tükenmişlik ve işten ayrılma niyeti arasındaki ilişki: Otel işletmesi çalışanları üzerine bir araştırma. İşletme Araştırmaları Dergisi, 9(1), 80-112. Erişim adresi: https://www.isarder.org/

Kaya, U. \& Özhan, Ç. K. (2012). Duygusal emek ve tükenmişlik ilişkisi: Turist rehberleri üzerine bir araştırma. Çalışma İlişkileri Dergisi, 3(2), 109-130. Erişim adresi: http://www.calismailiskileri.org/

Kızanıklı, M. \& Ünlüönen, K. (2016). Otel işletmelerinde davranış kuralı algısı ve iş doyumunun duygusal emek davranışı üzerindeki etkisinin belirlenmesi. Ege Akademik Bakış Dergisi, 16(3), 503-518. Erişim adresi: https://dergipark.org.tr/tr/pub/eab

Kültür ve Turizm Bakanlığı (2019). Turizm tesisleri: Turizm işletmesi belgeli tesisler. 01.02.2019. https://yigm.ktb.gov.tr/TR-9579/turizm-tesisleri.html

Lee, Y. K., Park, D. H. \& Yoo, D. K. (1999). The structural relationships between service orientation, mediators, and business performance in Korean hotel firms. Asia Pacific Journal of Tourism Research, 4(1), 59-70. doi: 10.1080/10941669908722031

Man, F. \& Öz, C. S. (2009). Göründüğü gibi olamamak ya da olduğu gibi görünememek: Çağrı merkezlerinde duygusal emek. Çalışma ve Toplum, 20(1), 75-94. Erişim adresi: https://www.calismatoplum.org/

Mehra, R. (2015). Emotional labour as a predictor of organizational commitment in selected call centres located in Chandigarh region. Clear International Journal of Research in Commerce \& Management, 6(11), 54-58. Retrieved from https://ijrcm.org.in/

Mesmer-Magnus, J. R., DeChurch, L. A. \& Wax, A. (2012). Moving emotional labor beyond surface and deep acting: A discordance-congruence perspective. Organizational Psychology Review, 2(1), 6-53. doi: 10.1177/2041386611417746

Meyer, J. P., Allen, N. J. \& Smith, C. A. (1993). Commitment to organizations and occupations: Extension and test of a three-component conceptualization. Journal of Applied Psychology, 78(4), 538-551. doi: 10.1037/0021-9010.78.4.538

Mikeska, J., Hamwi, G. A., Friend, S. B., Rutherford, B. N. \& Park, J. (2015). Artificial emotions among salespeople: Understanding the impact of surface acting. Marketing Management Journal, 25(2), 54-70. Retrieved from http://www.mmaglobal.org/publications/mmj/currentpast-issues/

Morris, J. A. \& Feldman, D. C. (1996). The dimensions, antecedents, and consequences of emotional labor. Academy of Management Review, 21(4), 986-1010. doi: 10.5465/amr.1996.9704071861

Mowday, R. T., Steers, R. M. \& Porter, L. W. (1979). The measurement of organizational commitment. Journal of Vocational Behavior, 14(2), 224-247. doi: 10.1016/0001-8791(79)90072-1

Naring, G., Briet, M. \& Brouwers, A. (2006). Beyond demand-control: Emotional labour and symptoms of burnout in teachers. Work \& Stress, 20(4), 303-315. doi: 10.1080/02678370601065182

Nikmah, U. \& Sulistyarini, I. (2017). Emotional labor and organizational commitment among hospital nurses: The mediating role of job burnout. Advances in Economics, Business and Management Research, 36, 426-434. doi: 10.2991/icbmr-17.2017.39

Oğuz, H. \& Özkul, M. (2016). Duygusal emek sürecine yön veren sosyolojik faktörler üzerine bir araştırma: Bat1 Akdeniz uygulaması. Süleyman Demirel Üniversitesi Vizyoner Dergisi, 7(16), 130-154. doi: 10.21076/vizyoner.265476

Pala, T. \& Sürgevil, O. (2016). Duygusal emek ölçeği: Ölçek geliştirme, güvenilirlik ve geçerlilik çalışması/emotional labor scale: A study of scale development, reliability and validity. Ege Akademik Bakış, 16(4), 773-787. Erișim adresi: https://dergipark.org.tr/tr/pub/eab

Pelit, E. \& Kılıç, İ. (2012). Mobbing ile örgütsel bağlılık ilişkisi: Şehir ve sayfiye otellerinde bir uygulama. Işsletme Araştırmaları Dergisi, 4(2), 122-140. Erișim adresi: https://www.isarder.org/

Rathi, N., Bhatnagar, D. \& Mishra, S. K. (2013). Effect of emotional labor on emotional exhaustion and work attitudes among hospitality employees in India. Journal of Human Resources in Hospitality \& Tourism, 12(3), 273-290. doi: 10.1080/15332845.2013.769142

Rupp, D. E., McCance, A. S., Spencer, S. \& Sonntag, K. (2008). Customer (in) justice and emotional labor: The role of perspective taking, anger, and emotional regulation. Journal of Management, 34(5), 903-924. doi: 10.1177/0149206307309261

Seçer, H. Ş. (2005). Çalışma yaşamında duygular ve duygusal emek: Sosyoloji, psikoloji ve örgüt teorisi açısından bir değerlendirme. Sosyal Siyaset Konferansları Dergisi, (50), 813-834. Erişim adresi: https://dergipark.org.tr/tr/pub/iusskd

Shukla, A. \& Pandey, S. (2019). Study of organizational commitment in relation to emotional labour. International Journal of Management Studies, 1(7), 33-41. doi: 10.18843/ijms/v6i1(7)/04

Sohn, H. K. \& Lee, T. J. (2012). Relationship between HEXACO personality factors and emotional labour of 
service providers in the tourism industry. Tourism Management, 33(1), 116-125. doi: 10.1016/j.tourman.2011.02.010

Sökmen, A. \& Sezgin, A. C. (2017). İş tatmini ve işten ayrılma niyetinin değerlendirilmesi: Otel işletmeleri sınır birim çalışanları üzerine bir araştırma. Journal of Tourism and Gastronomy Studies, 5(2), 237-250. doi: 10.21325/jotags.2017.79

Subramaniam, N., McManus, L. \& Mia, L. (2002). Enhancing hotel Managers' organisational commitment: An investigation of the impact of structure, need for achievement and participative budgeting. International Journal of Hospitality Management, 21(4), 303-320. doi: 10.1016/S02784319(02)00010-5

Tetik, S. (2012). Sağlık çalışanlarının örgütsel bağlılık düzeylerini belirlemeye yönelik bir araştırma. Sosyal ve Beşeri Bilimler Dergisi, 4(1), 275-286. Erişim adresi: https://dergipark.org.tr/en/pub/sobiadsbd

Turizm Bakanlığı \& Uluslararası Çalışma Örgütü (1994). Turizm endüstrisi işgücü araştırması 1993. Ankara: Levent Ofset Matbaacılık ve Yayıncılık Tic. Ltd. Şti.

Üngören, E. \& Çevirgen, A. (2016). Alanya'daki konaklama işletmelerinin genel yapısının analizi. The Journal of International Social Research, 9(43), 2223-2236. Erişim adresi: https://www.sosyalarastirmalar.com/yeni2020/anasay fa.html

Walters, G. \& Raybould, M. (2007). Burnout and perceived organisational support among front-line hospitality employees. Journal of Hospitality and Tourism Management, 14(2), 144-156. doi: 10.1375/jhtm.14.2.144

Wasti, S. A. (2002). Affective and continuance commitment to the organization: Test of an integrated model in the Turkish context. International Journal of Intercultural Relations, 26(5), 525-550. doi: 10.1016/S0147-1767(02)00032-9

Wiener, Y. (1982). Commitment in organizations: A normative view. Academy of Management Review, 7(3), 418-428. doi: 10.5465/amr.1982.4285349

Ye, T. (2016). Relationship between emotional labor, leader member social exchange and afective aommitment: A empirical study of clinicians in hospitals in China (Master dissertation). Universty Institute of Lisbon, Lisbon. Retrieved from https://repositorio.iscteiul.pt/bitstream/10071/13599/1/Tao\%20ye\%20Master \%20Thesis.pdf

Yürür, S. \& Ünlü, A. G. O. (2011). Duygusal emek, duygusal tükenme ve işten ayrılma niyeti iliş̧isi. ISGUC The Journal of Industrial Relations and Human Resources, 13(2), 81-104. 